\title{
R. J. FITCH'S LIST OF SASKATCHEWAN BUTTERFLIES
}

\author{
by John H. Masters, Box 7511 , Eastern Heights, St. Paul, Minnesota
}

From 1944 to 1956, Richard J. Fitch of Rivercourse, Saskatchewan, distributed a hand-copied list entitled "List of Arctic Species of Lepidoptera caught by R. J. Fitch at Lloydminster, Saskatchewan, C a nada." While only a few of the listed butterflies are truly "arctic species" and many of them were not caught at Lloydminster, the Fitch list represents 35 years of study in Saskatchewan and is an important record. Manitoba has comprehensive Lepidoptera lists by Wallis (1927), Brodie (1929) and Brooks (1942) and Alberta has an exhaustive list by Bowman (1951), but Saskatchewan has no equivalent; thus I feel that it is pertinent to make a permanent record of Fitch's work.

Very little has been ascertained concerning R. J. Fitch. He was born in 1886 in England, the son of Edward A. Fitch who at one time served as president of the British Entomological Society. As a boy, he and his six brothers collected British Lepidoptera and built large collections. Fitch emigrated to Canada as a young man and by 1919 had settled on a grain farm at Rivercourse, near Lloydminster, Saskatchewan. At Rivercourse he resumed his former hobby of collecting butterflies and by 1940 was in contact with many collectors and museums in North America and England. Fitch was extremely active in both exchanging and selling specimens and as a result most large collections in the U.S. and Canada contain at least a few of his specimens. Ehrlich and Ehrlich (1961) figure Erebia disa, Erebia epipsodea, Oeneis macounii and Speyeria mormonia in their keys from his specimens. Fitch died in the late 1950 's, and the disposition of his collection is not known.

Most of the specimens that Fitch sent out were in paper triangles folded from magazine pages, the data on them usually consisting of no more than the species name, "Fitch", the date of capture, and "Lloydminster." To "Lloydminster" many curators have arbitrarily attached either Saskatchewan or Alberta. There is no evidence that Fitch collected to any extent in Alberta, but he did collect some distance away from Lloydminster in Saskatchewan. Probably most of his specimens were captured on the premises of his farm at Rivercourse. However, many were not, as was indicated in a letter he wrote to G. S. Brooks on February 19, 1944: “... nevertheless I do a lot of my collecting north of North Saskatchewan River about 50 miles north of Lloydminster where there is a big timber limit and Indian agency .. . Up there I get among the spruce and tamaracwhich we don't see this side of the - . River. I get there ausonides, Brenthis fraija, frigga, aphirape and Chariclea, Oeneis macounii and jutta, Erebia disa and discoidalis none of which we ever see here - while up there one never sees Oeneis varuna and alberta and Erebia epipsodea which I get around here." In the late 1940's, Fitch began to assign the locality of "Harlan" to his specimens caught north of the North Saskatchewan River, but presumbably these came from a larger area than Harlan itself-Harlan being 35 miles north of Lloydminster. Only one other collector, P. F. Bruggeman, is known to have studied Lepidoptera in this region.

Lloydminster and Rivercourse are surrounded by parkland and prairie and are best assigned to the Transition Zone. The area is 30 per cent wooded in aspen and willow groves and the remainder is either prairie or planted to grain crops. The rainfall is less than 10 inches and the soil 
varies from dark brown loam to sand. North of the North Saskatchewan River the vegetation becomes distinctly more boreal and is best assigned to the Canadian Zone. Aspen, balsam poplar and willow forests are interspersed with black spruce and tamarack bogs. Rainfall is from 10 to 12 inches and black loam or peat soils predominate though there are a few sandy ridges. The principal agricultural crop is oats, but the area is only partially cleared for planting.

In the following list I have altered both the Latin names and the order of presentation to agree with modern taxonomic concepts. When the modern name differs from that originally used by Fitch, the Fitch name is added in parenthesis. All annotations in the list are mine, except when enclosed in quotation marks-in which case they have been taken from Fitch's letters to G. Shirley Brooks or Patrick J. Conway. The original lists contained only names without annotations except for the frequent affixing of offerata prices.

BUTTERFLIES COLLECTED BY R. J. FITCH in WEST CENTRAL SASKATCHEWAN

\section{HESPERIIDAE}

1. Amblyscirtes vialis Edw.--Roadside Skipper. "Scarce".

2. Euphyes vestris vestris Boisd., (Atrytone ruricola Boisd.)-The Dun Skipper.

3. Polites coras (Cr.), (P. peckius Kby.)-Peck's Skipper.

4. Polites themistocles (Latr.), ( $P$. cernes themistocles) - The Tawnyedged Skipper.

5. Polites siris dacotah (Edw.), ( $P$. mystic dacotah) - The Prairie Long Dash.

6. Hesperia manitoba manitoba (Scud.), (H. comma manitoba \& H. comma assiniboia Lym.)-The Manitoba Skipper. I have not allowed the sympatric occurrence of $H$. m. manitoba and $H$. m. assiniboia to stand; however the two have been found sympatric elsewhere and might possibly represent valid separate species.
7. Hesperia nevada (Scud.), (H. comma nevada) - The Nevada Skipper.

8. Oarisma garita (Reak.) - The Garita Skipper. This western species is quite common in this area.

9. Carteroccphalis palaemon mandan (Edw.), (C. palaemon)-The Arctic Skipper.

10. Pyrgus communis (Grt.) - The Checkered Skipper.

11. Erynnis icelus (Scud. \& Berg.), (Thanaos icelus) — The Dreamy Dusky Wing.

12. Erynnis persius (Scud.), (Thanaos persius)_-The Persius Dusky Wing. Fitch sometimes included Erynnis brizo (Boisd. \& LeC.) and $E$. juvenalis (Fabr.) on his lists. These would be very doubtful as this would be a considerable range extension northwestward and both of them normally feed on oak, which is not present here, in the larval stages.

13. Thorybes pylades (Scud.) - The Northern Cloudy Wing. Fitch sometimes recorded $T$. bathyllus Smith on his list along with pylades, but this was undoubtedly in error as bathyllus is a southern species.

14. Epargyreus clarus clarus (Cram), (E. tityrus Fabr.)--The Silverspotted Skipper.

\section{PAPILIONIDAE}

15. Papilio nitra Edw.-The Nitra Swallowtail. This was a very rare species and Fitch neither sold nor exchanged any examples with other collectors. His $P$. nitra may actually refer to that species or a form like Papilio kahli Cherm. \& Cherm.

- Papilio zelicaon Lucas--The Anise Butterfly. While $P$. zelicaon was sometimes listed, specimens were not believed to originate in Saskatchewan but rather in British Columbia where Fitch spent his winters during the late '40's and '50's.

16. Papilio machaon hudsonianus Clark-The Old World Swallowtail. "P. machaon hudsonianus 
breeds at Rutland in the sand hills thirty-five miles east of here, although I have never been able to catch one." Fitch also listed $P$. machaon dodi and $P$. machaon aliastia. His $P$. m. dodi probably came from Nordegg, Alberta and were collected by K. Bowmah. Certainly $P$. $m$. aliaska does not occur in Saskatchewan and I have no idea as to what this name might refer.

17. Papilio glancus canadensis R. \& J., ( $P$. turnus canadensis) - The Tiger Swallowtail.

\section{PIERIDAE}

18. Pieris occidentalis calyce Edw., ( $P$. occidentalis Reak., P. callyce and $P$. protodice Boisd. \& Lec.) The Western Checkered White. I am reluctant to retain $P$. protolice on the list although it could occur here along with $P$. occidentalis.

19. Pieris napi oleracea Harris---The Northern White.

20. Pieris rapae (L.) - The Cabbage Butterfly.

21. Colias eurytheme eurytheme Boisd., (C. eurytheme, C. e. alba, $C$. ariadne, $C$. keewaydin, $C$. e. form autumnalis) - The Orange Sulfur. While Fitch listed the five names as species or subspecies, they all represent infraspecific variants of Colias eurytheme.

22. Colias interior interior Scud.The Blueberry Sulfur. Colias interior is probably scarce here and possibly found only north of the North Saskatchewan River in wet environments where blueberries grow.

23. Colias alexandra christina Edw., (C. christina) - The Christina Sulfur.

24. Colias??, (C. eriphyle Edw.). Colias eriphyle is normally regarded as a subspecies of $C$. eurytheme, but the two do often occur together. Fitch's designation of eriphyle might refer to eriphyle or it could refer to Colias philodice Godart or Colias palaeno rhimpua Edw.-both of which are possible in the area. Another Colias that should be found in the Harlan area is Colias gigantea mayi Cherm. \& Cherm. which could easily be confused with $C$. interior if only males are captured.

25. Euchloe ausonides coloradensis (H. Edw.) or E.a.mayi Cherm.\& Cherm., (E. ausonides \& E. creusa Dbdy.-The Large Marble. The differences between subspecies ausonides and mayi are not especially distinct and a definite assignment to one or the other cannot be made at this time. Euchloe crensa should not occur in this area and those considered to be creusa by Fitch were probably only small examples of ausonides.

- Euchloe olympia rosa (Edw.), (Anthocaris o. rosa)-The Olympian Marble. This species appeared on some of Fitch's earlier lists but not on the later ones. While it should occur in Saskatchewan, it has not otherwise been found here and its presence in the Lloydminster area needs to be confirmed.

DANAIDAE

26. Danaus plexippus plexippus (L.), (D. menippe) - The Monarch.

\section{SATYRIDAE}

27. Lethe eurydic? fumosus (Leussler), (Enodia eurydice) - The Eyed Brown.

28. Coenonympha tullia benjamini $\mathrm{McD} .,(C$. inornata benjamini) The Prairie Ringlet.

29. Cercyonis pegala ino (Hall), (C. alope, C. nephele \& C. olympus)The American Grayling. Cercyonis pegala subspeciation is complex and uncertain; specimens from $\mathrm{Saskatchewan}$ are best designated as ino (type locality at Calgary, Alberta). By applying three names to the "Lloydminster" population, Fitch indicates that they are quite variable in this region-a condition not uncommon for the species. 
30. Oeneis uhleri varuna ( $\mathrm{Edw}$.), (O. varuna)-The Prairie Oeneis. A common spring species on virgin prairie.

31. Oeneis macounii (Edw.) - Macoun's Arctic. "One of our three scarcest species." Oeneis macounii was found only north of the North Saskatchewan River where it was possibly confined to sandy ridges with jack pine (see Masters \& Sorensen, 1968). Macounii has a biennial cycle and Fitch took it only in odd-numbered years.

32. Oeneis alberta alberta Elwes, $(O$. daura alberta) - The Alberta Oeneis. A species that flies on virgin prairie very early in May.

33. Oeneis jutta ridingiana Cherm. \& Cherm., (O. jutta) - The Bog Oeneis. Found only north of the North Saskatchewan River where it is confined to bogs.

34. Erebia disa mancinus Dbdy.-The Spruce Erebia. "One of our three scarcest species." Fitch did not collect Erebia disa until 1942. It was encountered only on the north side of the North Saskatchewan River and he believed that it was biennial and flew only in evennumbered years - a conclusion that was probably incorrect.

35. Erebia discoidalis discoidalis Kby. -The Red-disced Erebia. Fitch was contradictory on this species, sometimes indicating that he found it only in the boreal zone near Harlan and at other times that he found it only south of the River at Rivercourse. It is my guess that it was encountered both places but most commonly in sphagnum bogs north of the river. "Erebia discoidalis flies the last two weeks of May only."

36. Erebia epipsodea freemani Ehrlich, (E. epipsodea)-The Common Erebia. Erebia epipsodea flew during June only in the prairie regions.

\section{NYMPHALIDAE}

37. Limenitis arthemis rubrofasciata (B. \& McD.), (Basilarchia a.
mbrofasciata)-The White Admiral.

38. Limenitis archippus archippus (Cr.), (Basilarchia archippus)The Viceroy.

39. Vanessa atalanta (L.) - The Red Admiral.

40. Vanessa virginiensis (Drury)-Hunter's Butterfly.

41. Vanessa cardui (L.) - The Painted Lady.

42. Nymphalis j-album (D. \& S.), (Aglais j-album) - Compton's Tortoise Shell.

43. Nymphalis californica (Boisd.), (Aglais californica) - The California Tortoise Shell. Nymphalis californica swarmed at Rivercourse in September of 1945; it had only been taken once previously.

44. Nymphalis milberti (Gdt.), (Aglais milberti)-Milbert's Tortoise Shell.

45. Nymphalis antiopa (L.) (Aglais antiopa)-The Mourning Cloak.

46. Polygonia satyrus (Edw.)-The Satyr Angle Wing.

47. Polygonia faunus (Edw.) - The Green Comma.

48. Polygonia progne (Cr.), (P. progne \& P. zephyrus Edw.)The Gray Comma. In some lists Fitch indicated both $P$. progne and $P$. zephyrus; I suspect that only progne was encountered. Polygonia progne is a very variable species and is often confused with $P$. zephyrus or $P$. gracilis in the western part of its range, as was done by Puckering \& Post (1960).

49. Phyciodes tharos (Dry.), (P. tharos \& $P$. tharos var. pascoensis) -The Pearl Crescent.

50. Phyciodes batesii (Rkt.) - Tawny Crescent. This is a northwestward range extension for this species, but there is no reason why it shouldn't be found here.

51. Phyciodes campestris (Behr.)The Western Crescent. 
52. Chlosyne gorgone carlotta (Boisd. \&LeC.), (Phyciodes ismeria B. \& L.) - The Gorgone Crescent.

53. Boloria salene atrocostalis (Huard), (B. myrina Cr.)-The Silver-bordered Fritillary.

54. Boloria bellona jenistai Stal. \& Turn., (Brenthis bellona) - The Meadow Fritillary.

55. Boloria frigga saga (Staudinger). - The Saga Fritillary. A species usually associated with willow bogs, $B$. frigga was encountered by Fitch only north of the North Saskatchewan River and regarded as one of the three rarest butterflies in his area.

56. Boloria freija nabokovi Stal. \& Turn., (Brenthis freija tarquinius Curt.) - The Freija Fritillary. "If you want to catch Brenthis freija, you have to catch them just before Victoria Day (23 May)." Boloria freija is another bog species encountered only north of the North Saskatchewan River.

- Boloria alberta (Dbdy.) - The Alberta Fritillary. This species appeared on a couple of Fitch's lists, but not on the later ones$B$. alberta is highly improbable in Saskatchewan.

57. Boloria titania grandis (B. \& McD.). (Brenthis chariclea grandis)-The Purple Lesser Fritillary. A not uncommon singlebrooded species which flies in late July and August rather than early in the year like other members of the genus.

58. Boloria eunomia dawsoni (B. \& McD.), (Brenthis aphirape triclaris Hbr.)-The Bog Fritillary. A species restricted to bogs and only found north of the North Saskatchewan River by Fitch. Single-brooded and flying in midJune.

59. Speyeria callippe calgariana (McD.), (S. nevadensis calgariana)-The Callippe Fritillary. This was the rarest of the Speyeria species encountered in the area.

60. Speyeria atlantis dennisi (Gun- der), (Speyeria lais Edw.) - The Prairie Fritillary.

61. Speyeria mormonia eurynome (Edw.), (S. eurynome) - The Mountain Silverspot. One of the easternmost localities for this species which was not uncommon on the prairie here.

62. Speyeria cybele pseudocarpenteri (Cher. \& Cher.) - The Great Spangled Fritillary.

63. Speyeria aphrodite mayae (Gunder), (S. a. manitoba Cher. \& Cher.) - The Aphrodite Fritillary.

64. Euptoieta claudia claudia (Cr.)The Variegated Fritillary.

LYCAENIDAE

65. Incisalia augustinus augustinus (Westwood), (Thecla augustinus) -The Bog Elfin. An early season species that was encountered only in boreal elements north of the North Saskatchewan River.

66. Incisalia polios Ck. \& W., (Thecla polios) - The Hoary Elfin.

67. Strymon melinus humuli (Harris), (S. melinus Hbr.) - The Gray Hairstreak.

68. Chrysophanus titus titus (Fbr.), (Strymon titus) - The Coral Hairstreak.

69. Lycaena thoe (G-M.), (Heodes thoe)-The Bronze Copper.

70. Lycaena xanthoides dione Scud., (Heodes dione)-The Great Copper.

71. Lycaena helloides (Boisd.), (Heodes helloides)_The Purplish Copper.

72. Lycaena dorcas dorcas Kby., (Heodes dorcas) - The Dorcas Copper.

73. Lycaeides argyrognomon scudderii (Edw.), (Lycaena scudderii) -The Northern Blue.

74. Lycaeides melissa melissa (Edw.), (Lycaena melissa)_The Melissa Blue.

75. Plebejus saepiolus saepiolus (Boisd.), (Lycaena saepiolus)The Greenish Blue.

- Plebejus acmon (W. \& H.), (Lycaena acmon)-The Acmon Blue. Undoubtedly recorded due to a misidentification. $P$. acmon should not reach this far north. 
76. Plebejus aquilo lacustris Freeman, (Lycaena aquilo rustica Edw.) - The Arctic Blue.

77. Everes amyntula albrighti Clench, (Lycaena amyntula)-The Western Tailed Blue.

78. Glaucopsyche lygdamus couperi Grote, (Lycacna couperi) - The Silvery Blue. A species flying in late May and June which Fitch only found in the boreal region north of the North Saskatchewan River.

79. Celastrina argiolus lucia (Kby.), (Lycaena lucia) - The Spring Azure.

I am grateful to Patrick J. Conway of Chicago, Illinois for the loan of his correspondence file with R. J. Fitch and for the loan of specimens in his collection that were collected by Fitch; to L. Paul Grey of Lincoln, Maine for help in the analysis of Speyeria species collected by Fitch; and to W. Harvey Beck of the Manitoba Museum of Man and Nature for the loan of the G. Shirley Brooks correspondence file which contains a series of letters with R. J. Fitch.

\section{LITERATURE CITED}

Bowman, K. 1951. An annotated list of the Lepidoptera of Alberta. Canadian J. of Zool., $29: 121-165$.

Brodie, H. J. 1929. A preliminary list of the Lepidoptera of Manitoba. Trans. Royal Canadian Inst., $17: 81-101$

Brooks, G. S. 1942. A checklist of the butterflies of Manitoba. Canadian Ent., 74:31-36.

Ehrlich, P. R. \& A. H. Ehrlich. 1961. How to know the butterflies. Wm. C. Brown Co.. Dubuque, Iowa.

Masters, J. H. and J. T. Sorensen, 1968. Bionomic notes on the satyrid butterfly, Oeneis macounii at Riding Mountain, Manitoba. The Blue Jay, 26(1):38-40.

Puckering, D. L. and R. L. Post, 1960. Butterflies of North Dakota. Publ. 1., Dept. of Agr. Ent., North Dakota Agricultural College.

Wallis, J. B. 1921. A colour key to the Manitoban butterflies. Nat. Hist. Soc. Manitoba Publ.

\section{AN OBSERVATION OF INTERSPECIFIC BEHAVIOUR IN DRAGONFLIES}

by Victoria Rider, 824 New Hampshire Ave. N.W., Washington, D.C.

During the summer of 1968 at Emma Lake, Saskatchewan, a male Aeshna interrupta dragonfly was seen to exhibit both sexual and aggressive, or predatory, behaviour toward a male Libellula quadrimaculata dragonfly. The observation was recorded during the course of a preliminary study of aggressive behaviour in L. quadrimaculata in which males of the species were glued live, by the legs, to frequently used perches projecting over shallow water areas. Usually these libellulid "models" were investigated by other male $L$. quadrimaculata. On one occasion, however, a male Aeshna interrupta landed on the thorax of the model and appeared, initially, to be attacking it vigorously with its mandibles. It subsequently remained nearly motionless for the next few minutes, still perched on the model's thorax. The aeshnid then began curving its abdomen forward and succeeded in grasping the model anteriorally for a few seconds with its abdominal claspers. This last act strongly resembled normal mating behaviour in dragonflies, where the male's first action is to adopt the "tandem position" with the female.

After several more minutes of perching on the model's thorax the $A$. interrupta flew off. The entire interaction lasted approximately six minutes. Examination of the L. quadrimaculata model revealed that a large section of the dorsal side of its thorax and the back of its head had been eaten.

This interaction is significant in two respects. First, it demonstrates the relatively low degree of speciesspecificity which can characterize interactions between dragonflies. Aeshna interrupta is a considerably larger species than Libellula quadrimaculata, and the bodies of male aeshnids display brilliant blue and yellow coloring in contrast to the brown coloration of $L$. quadrimaculata. A. interrupta dragonflies spend the vast majority of their active hours on the wing, frequently flying at 